\title{
STEM Competency to Support Technology Advancement and National HRST Performance
}

\author{
Elmi Achelia, Indri Juwita Asmara, Maulana Akbar, Nani Grace Berliana, and Muhammad Tasrif
}

\begin{abstract}
The era of globalization is the era of technological competition where the strength of a country is determined by technology advancement that will encourage economic growth. Technology advancement is dependent on human resource capacity. In that context, human resource with the ability to create and utilize the technology is needed, which is derived from STEM education. Human resource closely related to the development of S\&T can be regarded as Human Resource in Science and Technology (HRST). Indonesia as a developing country has the potential to compete in global world, supported by positive economic growth and demographic bonuses. However, it is not good enough on some indicators in the development of S\&T. Also, Indonesia still act as an adopter or technology importer. Therefore, we study how Indonesia is as an adopter or switch as an innovator by develop the Indonesia's HRST dynamics model. The model simulation shows that there is a significant difference in economic growth through the changing mode of technology advancement with the support of STEM competent HRST.
\end{abstract}

Index Terms-System dynamics, STEM competency, HRST, technology, economy.

\section{INTRODUCTION}

The era of globalization is the era of technological competition. Technology is an increasingly important element of globalization and of competitiveness [1]. Every country is competing to advancing technology. It is because technology has been central to both economic growth and many elements of social welfare [2]. Technology gives great impact on economic growth and sustainable development. Sachs stated the need for long-term technological advancement to sustain economic growth. An economy without technological innovation will not prevent stagnation unless it continually advances its technological capacity [3]. In the advancing of technology, human resources are an important factor as the subject who develop and use technology. Therefore, human resources are the main focus in development.

Human resources closely related to the development of science and technology can be regarded as Human Resource in Science and Technology (HRST), refers to the definition in the Canberra Manual. HRST determines technological advancement and economic growth [4]. In the context of technology advancement, the HRST required to have certain competencies to drive technnology innovation. Technological advance is very complementary with higher skills and more education. As a result, education and skills are becoming

Manuscript received October 9, 2017; revised May 1, 2018.

Elmi Achelia is with the Center of Science and Technology Development Studies, Indonesia Institute of Science (LIPI), Indonesia (e-mail: elmiachelia@gmail.com). more important in international competitiveness [1]. Jang identified 21 st century STEM competencies to meet the demand for skills in workplace, which includes important skills (such as critical thinking, complex problem solving, etc.) and important knowledge (such as Mathematics, Computers and Electronic, etc) [5]. Accordingly, the NSB report shows that the STEM workforce, consists of a many types of STEM-capable workers who employ significant STEM knowledge and skills in their jobs, is extensive and critical to innovation and competitiveness [6]. So we highlights that HRST with STEM competency is the focus for technological advancement, which will be named as STEM-HRST in the next section of discussion.

STEM, stands for Science Technology Engineering and Mathematics, first coined in the US in early 2000 in conjunction with skilled workforce shortage problem, which was then implemented to STEM education that aims to fostering STEM workforce who have the competency to be innovative in developing technology. STEM education is then adapted by many countries in the world to address similar issue.

The role of technology and innovation for economic growth, for example in the United States as a leader in technology, that technological innovation drives 75 percent of economic growth since the second world war. With contributions to Total Factor Productivity (TFP), innovations are growing at least 55 percent of US productivity growth from 1959 to 2005 due to innovation [7]. In accordance with that, there is an increasing demand for STEM worker. Employment in STEM occupations grew by 10.5 percent or 817.260 jobs, between May 2009 and May 2015, compared with 5.2 percent net-growth in non-STEM occupations [8].

Over the next twenty-five years, many Asian economies will becoming technology innovators [3]. Indonesia is in this region and will be so affected that it needs to be prepared to face the competition.

Indonesia as a developing country has the potential to compete in a global world, supported by positive economic growth and demographic bonuses that ensure the availability of human resources. Not only quantity, the quality of human resources is also increasing, seen from increased participation in higher education. The World Bank data shows rise percentage of gross enrollment ratio on tertiary education from $14.88 \%$ at 2000 to $31.26 \%$ at 2013 . However, on some indicators in the development of science and technology, Indonesia is left behind compared to the closest countries in ASEAN [9]. In addition, regarding the technology advancement, Indonesia is a net importer of advanced technologies developed in the developed countries [10]. Net importer country is adopter of technlogy, and has less 
capability to invent or innovate the technology. Based on USAID analysis, the skills that Indonesian workers need to improve in order to meet market demand include foundational skills, work readiness skills, and on-the-job-training skills, i.e. reading comprehension, active listening, oral comprehension, speaking, written expression, written comprehension, deductive reasoning, information ordering, problem sensitivity, mathematical reasoning, critical thinking, complex problem solving, system analysis, time management, interacting with computer, documenting information, judgment and decision making, communicating, using various software tools. The skills and knowledge mentioned are the scope of the STEM competency described earlier.

Therefore it is necessary to study how will Indonesia in the future if its still act as an technology adopter or switch as an innovator. In this study we develop the Indonesia's HRST model to illustrate the interconnection of various factors, namely the potential of STEM-HRST, economic growth, and technology advancement. With dynamics models being developed, simulations are performed with various scenarios to show the factors observed. We assume that there is a significant difference in economic growth through the changing mode of technology advancement with the support of STEM-HRST.

This chapter outline in general interconnection between Human Resources in Science and Technology (HRST) related to technology advancement and economic development, and an emphasis of Indonesia. The next section, we will discuss methodology and basic concept of HRST, Technology advancement and STEM. Later in section 3, we will describe the model of HRST. In section 4, we will discuss the analysis of running scenarios on the model. Finally, in section 5, we will draw some conclusions.

\section{METhodology AND BASIC CONCEPT}

This research focus on HRST is conducted by modelling Indonesia's HRST using System Dynamics method. System dynamics is a methodology and mathematical modeling technique. System Dynamic is chosen for several reasons. First, it can handle dynamic complexity when the real world is not so simple, System Dynamics emphasizes multiple loop, multiple state, nonlinear character of the feedback system in which we live [11]. The stages of this study are conducted according to the stages of the System Dynamics method [12], starting from the identification of the problem as described in the introduction. Then the system conceptualization to determine variables and interconnection between variables. The next stage is a model formulation. With the developed model, we run simulation for some designed scenarios. We use Vensim software as tools to develop the dynamics model and run the scenarios.

Economic growth is used as an indicator of economic development. Frankema and Lindblad analyze long-run growth paths, is aided by a decomposition into two main sources of economic growth: accumulation of factors of production and total factor productivity (TFP) [13]. In order to execute this growth, a Cobb-Douglas production function is used, including labor, physical capital and human capital.

According to Sachs, that there are two basic modes of advancing technology. One is innovation (developing one's own new technologies) and the other is adoption (introducing technologies that have been devised elsewhere)[3]. Higher export ratio shows innovation mode, and higher import ratio shows adoption mode. To referring technology advancement, The World Bank describe technological progress -improvements in the techniques (including firm organization) by which goods and services are produced, marketed, and brought to market - is at the heart of human progress and development [2].

Based on the definition proposed in Canberra Manual, Human Resources in Science and Technology includes people who have completed third-level education in the field of science and technology (based on ISCED) and or people who employed in S\&T occupation where the above qualifications are normally required (based on ISCO) [14]. HRST on education comprises ISCED category 5, 6, and 7 on 7 S\&T fields of study, i.e. natural sciences, engineering and technology, medical sciences, agricultural sciences, social science, humanities, other fields [15]. ISCED category 5 describes education at the tertiary level, first stage, of the type that leads to an award not equivalent to a first university degree. ISCED category 6 describes education at the tertiary level, first stage, of the type that leads to a first university degree or equivalent. ISCED category 7 describes education at the tertiary level, second stage, of the type that leads to a postgraduate university degree or equivalent. People working in ISCO major group 1, 2, and 3 can be considered HRST . People working in ISCO major group 2 and more specifically university-level HRST. people working in ISCO major group 3 can be divided into three categories: (i) those with qualifications at ISCED categories 6 or 7 who are part of university-level HRST, (ii) those with qualifications at ISCED category 5 of the definition of technician-level HRST and (iii) those with lower qualifications. In addition to ISCO groups 2 and 3, some HRST-relevant occupations may be identified in major group 1 ("Legislators, Senior Officials and Managers") on three subgroups, i.e. "Production and Operations Department Managers" (subgroup 122), "Other Department Managers" (subgroup 123), which includes R\&D managers among others, and "General Managers" (subgroup 131). Indonesia's HRST is defined by mapping the appropriate national classification used in Indonesia, ie ISCO mapped to the Indonesian Standard Classification of Occupation named Klasifikasi Baku Jabatan Indonesia (KBJI) and ISCED reference on Indonesian education system. Based on that, Indonesia's HRST are people who graduated from 3-years Diploma (or higher) in the field of science and technology, and / or those who work in positions as specified in KBJI [16].

The concepts and definitions of STEM education do not apply universally, each country determines its various definitions. In the United States, STEM is defined as a field of science that includes mathematics, natural sciences, engineering, computer and information science, and social and behavioral sciences - the science of psychology, economics, sociology and political science [17]. STEM education in Indonesia was initiated through formerly the 
Ministry of Education and Culture, currently the Ministry of Research and Technology. STEM education in universities includes courses in mathematics and natural sciences, engineering, health, agriculture, and science education (mathematics and natural science education and technical education) in accordance with Constitution No. 12 year 2012 on Higher Education, which classifies 6 (six) science fields namely religion, humanities, social science, natural science, formal science (such as computing and mathematics), and applied sciences (such as health and engineering).

\section{HRST MODEL}

Indonesia's HRST model was dveloped in this study consist of variables to represent the interconnection of various factors. The main variables are STEM-HRST indicated by the graduates of higher education as supply and those who work as demand, economic growth indicated by GDP, technology level, and technology advancement.

Previous studies using system dynamics methods to model problems related to STEM, Science, Technology and Innovation, and Economy can be used as a reference to theoretically validate the constructive variables of the model. Model regional innovation systems in Mexico's case as an emerging economy shows the linkage of science and technology indicators, human resources (HR), budget, and research results in the sustainability of innovation [18]. The System Dynamics method is also used in the innovation system model developed by Uriona et. al. [19], where the model describes the structure and processes of science and technology in promoting economic growth, in which there are variables of research activities, human resources (HR), technology output, innovation capabilities, and budget. The dynamics model is also used to describe the strategies that influence research investment in Korea, related to innovation, technological development and GDP as an economic indicator [20]. In other models, system dynamics is also used to illustrate how technological changes affect economic growth from a micro and macroeconomic point of view [21]. The model illustrates the linkage between the economy subsystem, the labor subsystem, the population subsystem, the innovation subsystem, the payroll subsystem, and the research subsystem. Other model on the topic of STEM, a dynamic model is used in exploring the attractiveness of workers and firms towards STEM aimed at knowing the right policies that can be taken to address the decreasing interest in STEM in America and anticipating shortcomings [22]. STEM's wages and career risks - working years, foreign workers, and continuing education workforce - are factors that affect the career attractiveness of STEM.

From the literature review, it can be said that this model is different from the previous model by describing the relationship between STEM-HRST with economy and technology.

This HRST model consists of HRST subsystem, HRST demand subsystem, expected HRST subsystem, STEM-HRST supply subsystem, STEM education capacity subsystem, technology subsystem, and economy subsystem as shows in Fig. 1.

The data was used to build the model in this study are national workforce survey data namely Survei Tenaga Kerja Nasional (Sakernas) classified based on Indonesia's HRST definition [14], Indonesia's GDP trends, and import-export trends from National Statistic Bureau; as well as data of higher education graduates data classified by STEM field and non-STEM from Ministry of Research and Technology.

\section{A. STEM-HRST Supply Subsystem}

STEM-HRST Supply subsystem explain relationship between Expected STEM-HRST, STEM education capacity, and HRST subsystems as shows in Fig. 2. The availability of HRST stocks and the increasing HRST demand will determine the number of new HRST that must be produced from education, both STEM and non-STEM with the ratio determined from the technological level. Then the expected STEM-HRST can estimate the employment of STEM-HRST occupation by the labor market. It affects the number of STEM graduates required, which then encourages STEM education to provide the capacity. Ideally if the capacity is always fulfilled, it will deliver sufficient STEM education graduates for HRST stock supply.

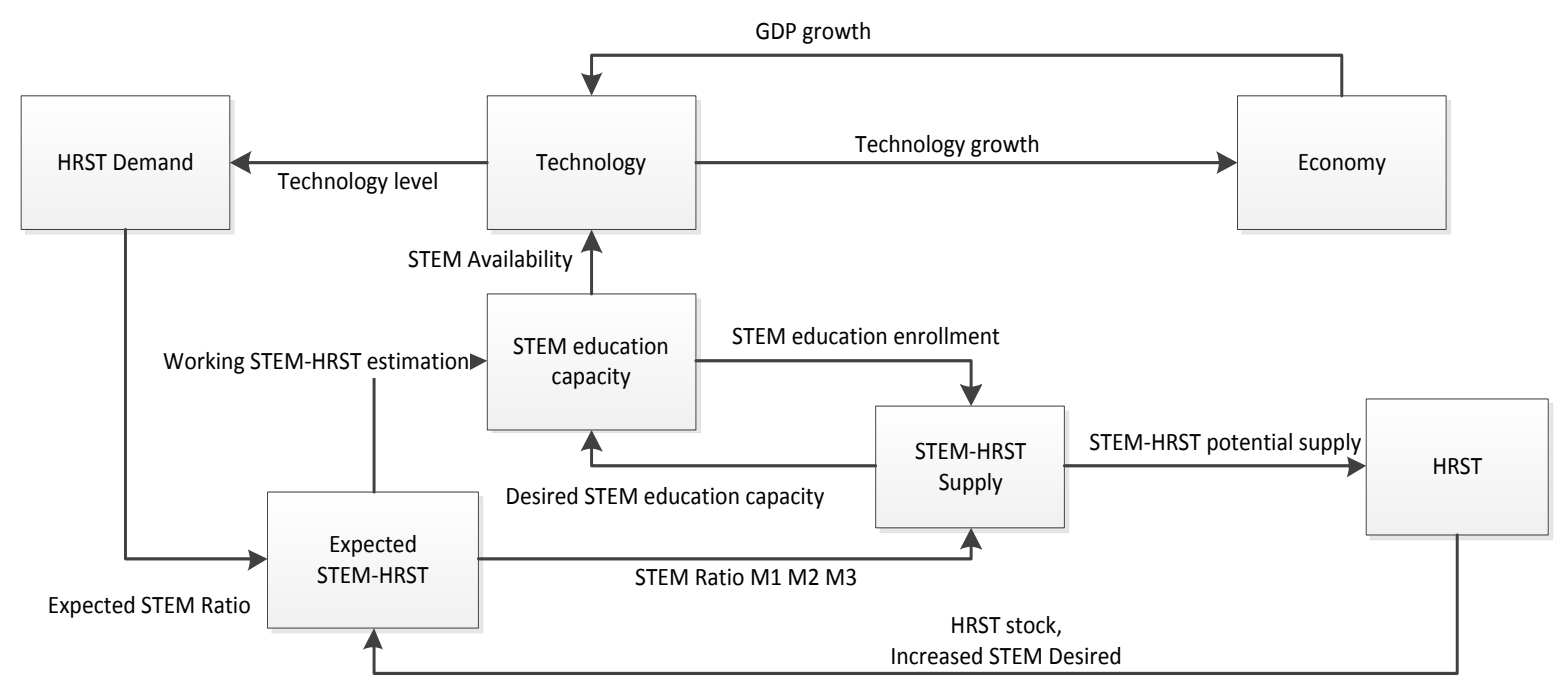

Fig. 1. Big picture of Indonesia's HRST model. 


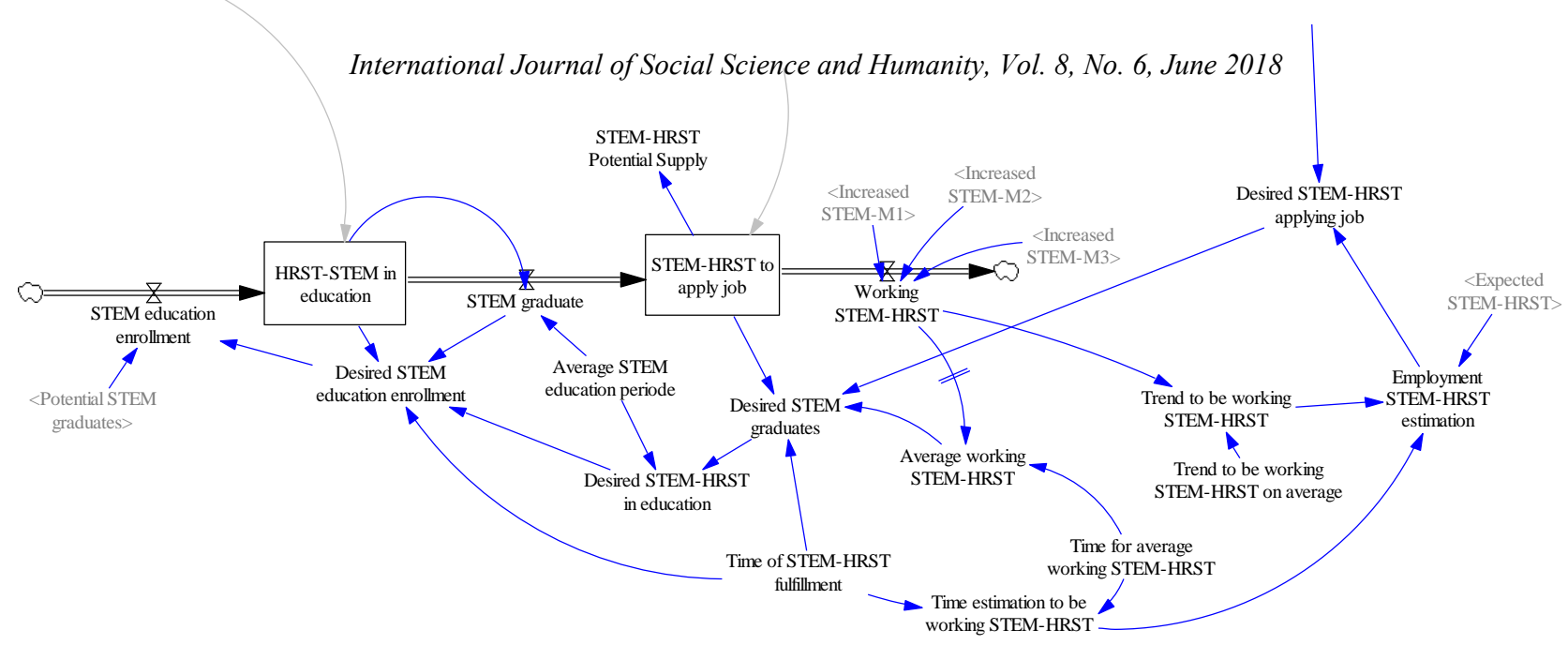

Fig. 2. STEM-HRST supply.

\section{B. HRST Subsystem}

HRST subsystem determines stock and flow of three Majors of HRST as shows in Fig. 3. There are internal flows from lower level occupation to the higher level, ie from Major 3 (Technician) to Major 2 (Professional) and from Major 2 to Major 1 (Manager). Each Major stock is increased by Inflow from overseas and domestic increases, also internal flow at Major 2 and Major 1. The domestic increased comes from STEM and non-STEM supply.

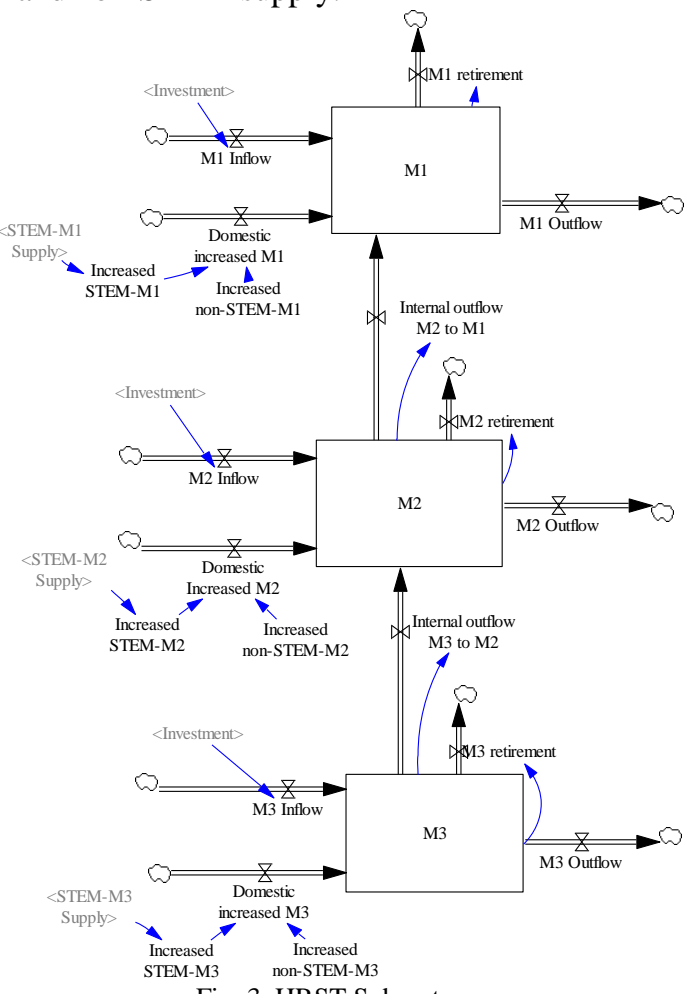

Fig. 3. HRST Subsystem.

\section{Economy Subsystem}

Economy subsystem describe economy growth with GDP as main indicator. GDP is calculated as an expenditure which is the sum of public consumption (C), investment (I), government expenditure $(\mathrm{G})$, also gap between import (M) and export $(\mathrm{X})$, calculated by (1)

$$
\mathrm{Y}=\mathrm{C}+\mathrm{G}+\mathrm{I}+\mathrm{X}-\mathrm{M}
$$

GDP is also calculated as a production function generated from the productivity of capital and labor which influenced by technology. The calculation of GDP $\left(\mathrm{G}_{\mathrm{q}}\right)$ is determined by
Growth rate of Capital $\left(\mathrm{G}_{\mathrm{K}}\right)$, Growth rate of Labor $\left(\mathrm{G}_{\mathrm{L}}\right)$, and Growth rate of Technology $\left(\mathrm{G}_{\mathrm{A}}\right)$ in the Cobb-Douglas production function in (2)

$$
\mathrm{G}_{\mathrm{q}}=\mathrm{G}_{\mathrm{A}}+\alpha \mathrm{G}_{\mathrm{K}}+\beta \mathrm{G}_{\mathrm{L}}
$$

Fig. 4 describe the Economy subsystem. The targeted GDP will be a trigger for desired capital, desired labor, and production supply which in turn will set the balance of consumption through export and import.

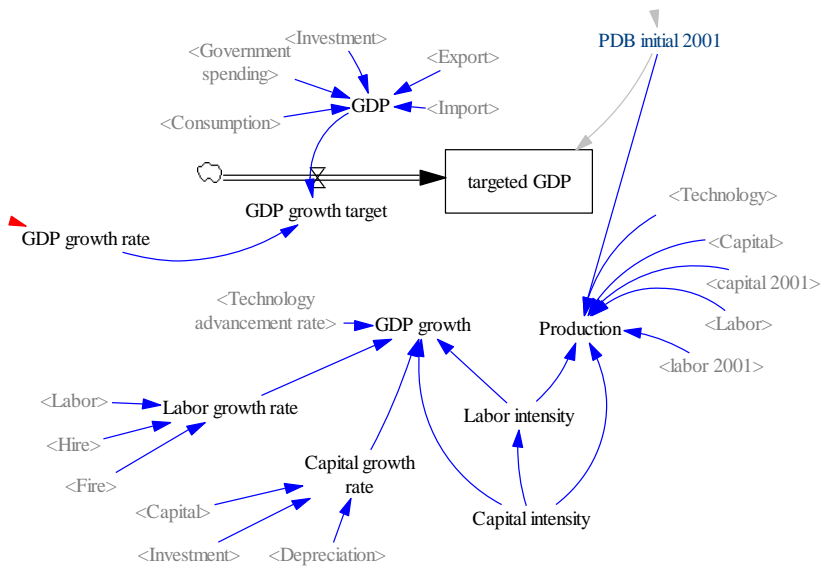

Fig. 4. Economy subsystem.

\section{Technology Subsystem}

Technology subsystem shows the technological levels that are affected by the economy and the availability of STEM-HRST supplies from education, in Fig. 5. This pointing the importance of STEM-HRST in catching up technological advancement. GDP growth rate drives technology advancement target and influenced by capital and labor, in accordance to Cobb-Douglas equation.

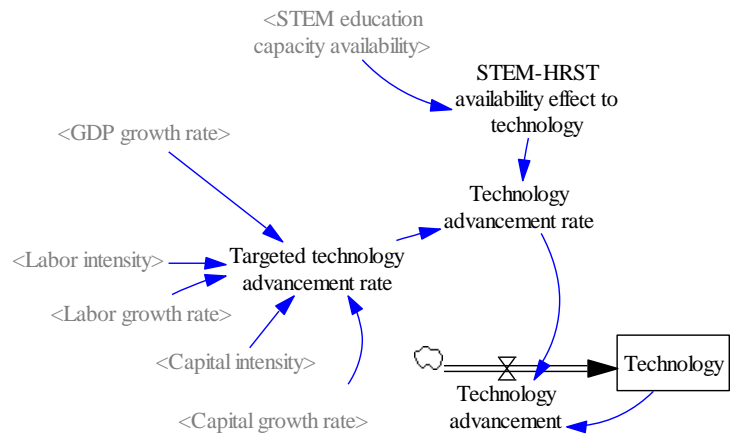

Fig. 5. Technology subsystem. 


\section{SCEnARIO ANALYSIS}

\section{A. Analysis of Base Behavior}

The developed model validation is done by comparing generated trend to historical data, from 2001 to 2013. In result we found GDP trend and GDP history have similar trend as describe in Fig. 6, and also HRST trend to HRST history in Fig. 7. We can conclude that this model is valid to be used in simulation scenarios.

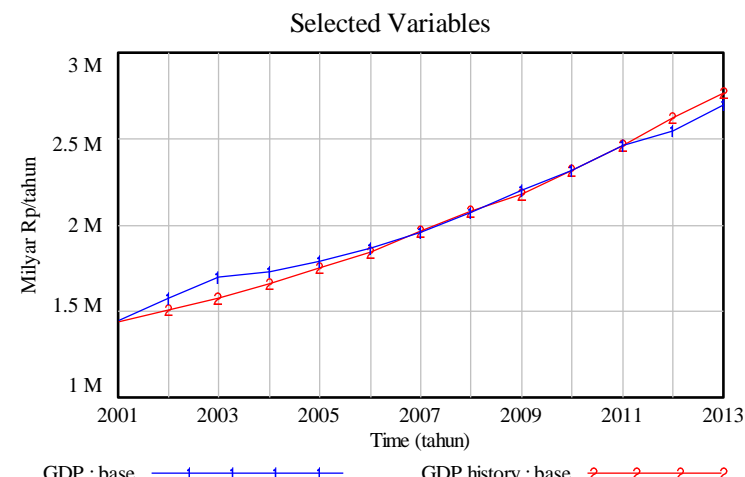

Fig. 6. GDP validation. Selected Variables

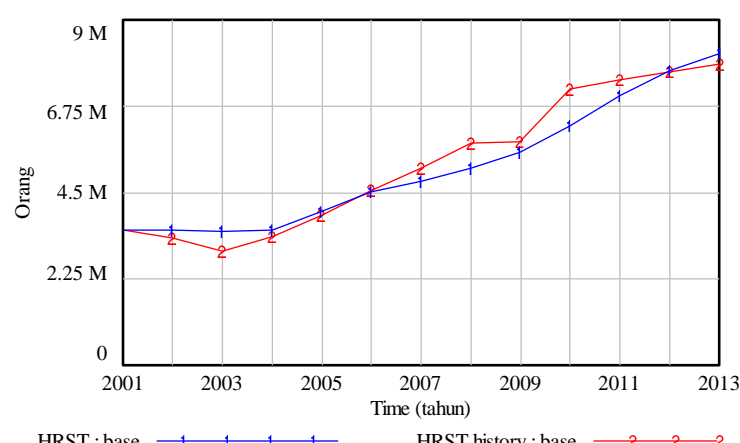

Fig. 7. HRST validation.

\section{B. Base Scenario}

To perform a simulation with various scenarios, it is necessary to determine the basic scenario that will be used as a comparison. Base scenarios are simulated according to historical conditions for the time range specified to be observed. This scenario is the basic comparison of the scenarios to be run with various modification conditions. Indonesia as a net-importer is shown at the variables in the economic, technological and HRST subsystems. Base scenario simulation results in Fig. 8 shown positive trend of GDP, Technology, STEM, and STEM-HRST until 2030.

Selected Variables

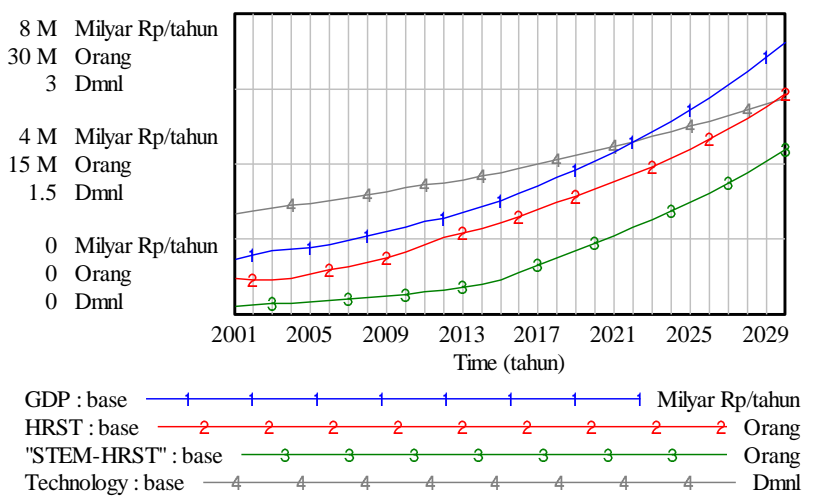

Fig. 8. Base scenario simulation result.

\section{Scenario of Adopter}

This scenario is running to show the condition of an increase in technology caused by technology adoption. The technological adoption mode characteristic is shown by the increasing import and declining ratio of STEM-HRST to technology. In this scenario, the ratio of STEM-HRST is lower than it is in Base Scenario but import is increased. Because the technology is imported, so STEM-HRST is less-important, this is indicated by the decreasing increased HRST and STEM-HRST demand. Decrease in demand leads to a decline Employment STEM-HRST estimation, thereby reducing the attractiveness to become a STEM-HRST through education. As a result there is a decrease in STEM education enrollment, which in turn leads to decreasing STEM graduates as well as the potential for STEM-HRST supply.

Under these conditions, the economic increase (GDP) is lower than the Base Scenario (see Fig. 9). Fig. 10 shows the number of HRST and STEM-HRST decreased but the ratio of STEM-HRST to HRST is higher than in Base Scenario condition, this is generally because STEM-HRST works as technology user or operator, not as a technology creator.
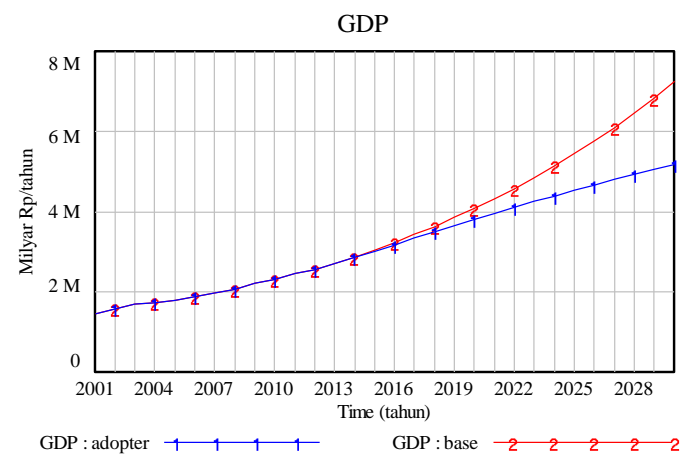

Fig. 9. Comparing GDP on scenario of adopter. Selected Variables

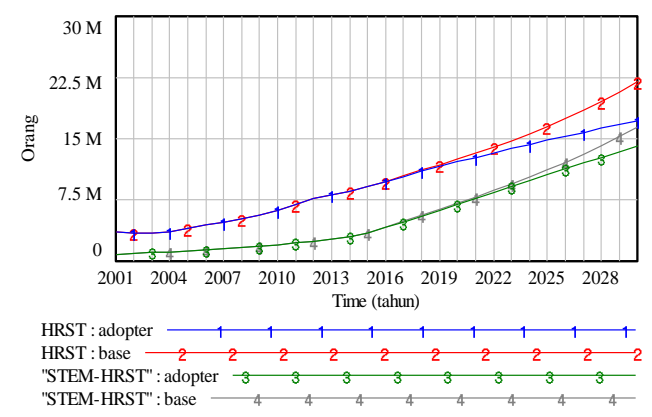

Fig. 10. Comparing HRST and STEM-HRST on scenario of adopter.

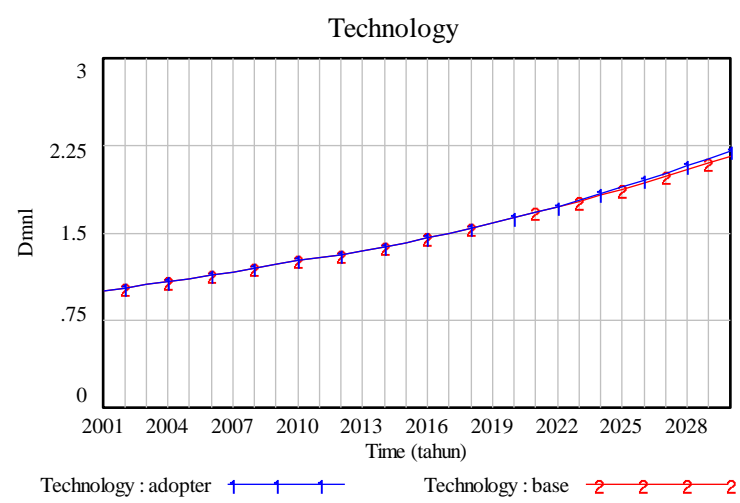

Fig. 11. Comparing Technology on scenario of adopter. 
Fig. 11 shows that technology is still advancing in adopter mode. It can be explained that the required technology remains met by import.

\section{Scenario of Innovator}

This scenario of technology innovation characterized by increasing of STEM-HRST and the decreasing of import. On the innovator scenario, we get the results as shown in graphics below. Fig. 12 shows the GDP on technology mode shows a higher increase than the Base scenario. While the technology level and HRST trends is shown respectively in Fig. 13 and Fig. 14.

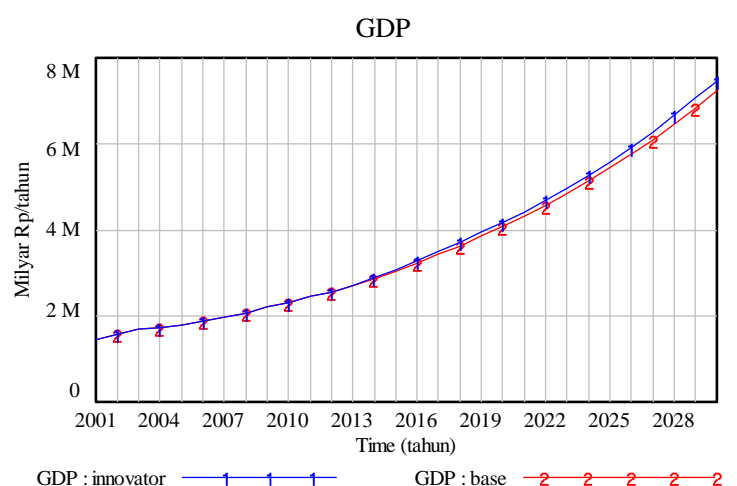

Fig. 12. Comparing GDP on scenario of innovator.

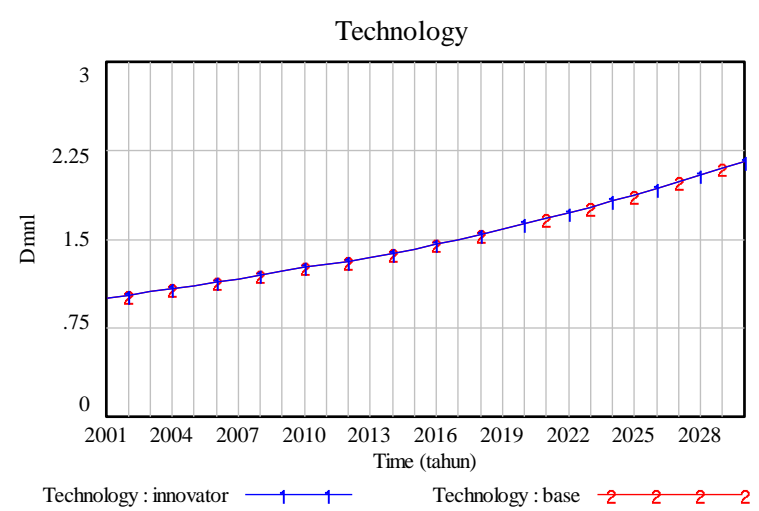

Fig. 13. Comparing Technology on scenario of innovator.

In this scenario, the technology level is slightly higher than it is in Base scenario. Likely, the increase in technology level is determined by imports. So when imports are lowered, even though STEM-HRST increases, it isn't enough to push the higher level of technology. This might considering that the innovation capacity in the model is still low.

Selected Variables
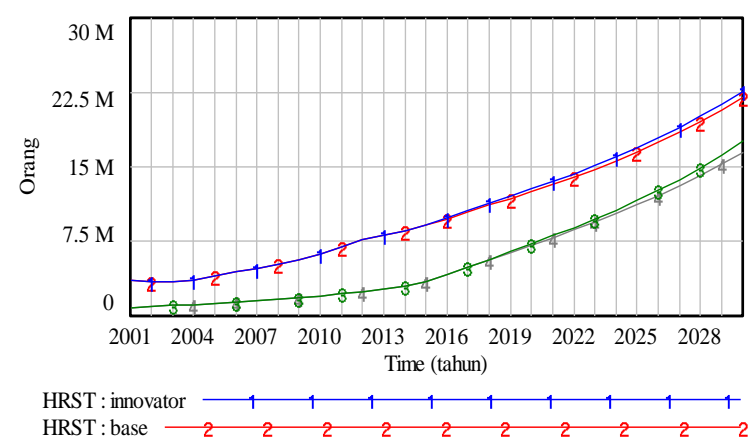

"STEM-HRST" : innovator $\begin{array}{lllllll}3 & 3 & 3 & 3 & 3 & 3 & 3\end{array}$

"STEM-HRST" : base $\begin{array}{llllllllll}4 & 4 & 4 & 4 & 4 & 4 & 4 & 4\end{array}$

Fig. 14. Comparing HRST and STEM-HRST on scenario of innovator.
Mode of innovation will improve the economy (GDP). While the effect on technological improvement will occur if the expected STEM-HRST fulfilled by the supply potential of the STEM graduate of education, which is linked to the support of available educational capacity. STEM-HRST is needed to deliver innovations, it cause increasing in the employment of STEM-HRST occupation, so as increasing the attractiveness to become STEM-HRST. We assumed STEM educational capacity is align, so that the potential supply of STEM-HRST increased and employed so that the number of STEM-HRST in labor market is also increased.

In the scenario of innovator, it is also shown the influence of the STEM education capacity to GDP and technology. Decrease in capacity causes a decrease in the potential supply, so that the employment of STEM-HRST is decreased. However this does not significantly lower the level of technology and GDP, seen with almost coincide graph. Comparison of innovator scenario simulation results with capacity as needed or only half of the required capacity can be seen on Fig. 15.

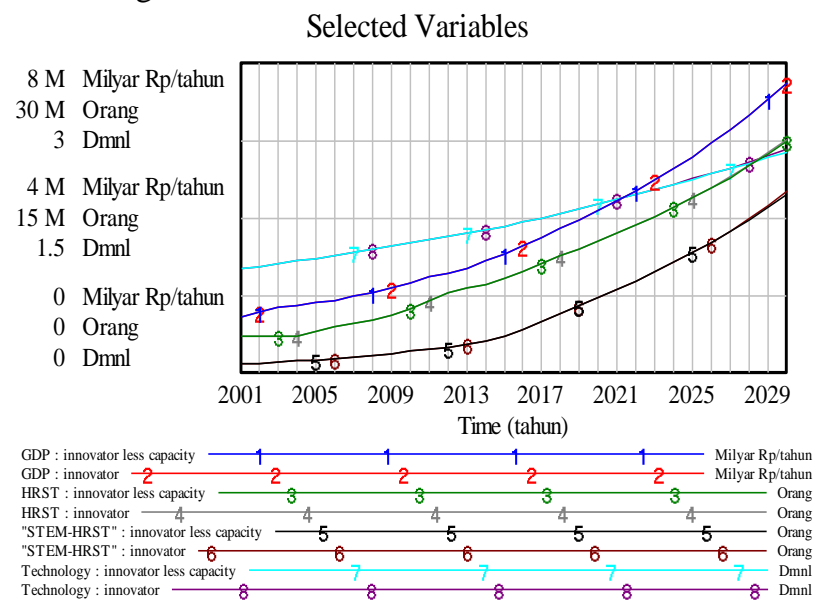

Fig. 15. Scenario of innovator with difference STEM education capacity.

\section{CONCLUSION}

This research developed the structure of Human Resource in Science and Technology (HRST) model with emphasize at the STEM competency issue, shows the correlation between human resource potential of STEM competence and its impact on development. STEM, stands for Science, Technology, Engineering, and Mathematics, implemented in study fields within higher education to deliver STEM competent graduates. With the model simulation, we can see the projection of STEM graduates, STEM competent who employ as HRST (STEM-HRST), technology and economic growth. Potential STEM-HRST counted from STEM fields higher education graduates who work as HRST. STEM-HRST include the position of Manager, Professional and Technician. The economic growth is determined by Gross Domestic Product (GDP). GDP is calculated based on expenditure approach which is the sum of public consumption, investment, government expenditure, and import-export. GDP is also calculated as a derived of the Cobb-Douglas production function which is the sum of outputs from the productivity of capital and labor owned, and influenced by technology. Technological advancement occurs in two ways, innovation and adoption. Innovators achieve technological 
progress by developing their own technology. Meanwhile, adopters achieve technological progress with technology developed by other parties. In the model, the innovation mode is shown by the increasing ratio STEM-HRST to the total HRST and the decreasing of import fraction on the production function which is the function of GDP calculation, and vice versa for adoption mode. The simulation result of scenario of innovator shows the increasing of STEM competent ratio in HRST along with the decreasing of import and increasing of level technology and economy (GDP). So it can be said that the model proves that STEM competency is able to encourage economic growth of Indonesia. While the simulation result of scenario of adopter shows the ratio of competence STEM-HRST is increases along with the increase in imports, indicating STEM-HRST work as a technology user or operator, not as the creator of technology. Technology level is still increasing by fulfilling the required technology with imports. In the scenario of innovator also simulate the decreasing STEM education capacity (while non-STEM education capacity is fixed). The simulation results show that the STEM educational capacity is not generate significant impact to the economic and technological growth.

From the running scenarios, it can be concluded that the STEM-HRST absorbed in the labor market, aligned with its competency, will drive technology advancement and encourage economic growth. On the other hand, the innovator mode will be more useful to improve the economy as reflected by the higher increase of GDP.

\section{REFERENCES}

[1] C. Dahlman. (2007). Technology, globalization and international competitiveness: Challenges for developing countries. Industrial development for the $21^{\text {st }}$ century, Department of economic and social affairs of United Nations. [Online]. Available: http://www.un.org/esa/sustdev/publications/industrial_development/1 2.pdf

[2] Global Economic Prospect. Technology Diffusion in the Developing World. 2008 The International Bank for Reconstruction and Development / The World Bank.

[3] S. D. Jeffrey, McArthur, and W. John, "Technological advancement and long-term economic growth in Asia," Technology and the New Economy, pp. 157-185, 2002.

[4] A. E. Asmara, I. Juwita, A. Maulana, and T. Muhammad. (July 2017). The Impact of Education on National HRST Performance. International Journal of Social Science and Humanity. [Online]. Available:

http://www.ijssh.org/index.php?m=content\&c=index\&a=show\&catid $=90 \& \mathrm{id}=1243$

[5] H. Jang, "Identifying 21st century STEM competencies using workplace data," Journal of Science Education and Technology, 2015.

[6] National Science Board. (2015). Revisiting the Stem Workforce. [Online]. https://www.nsf.gov/pubs/2015/nsb201510/nsb201510.pdf

[7] A. P. Carnevale, N. Smith, and M. Melton, STEM Science Technology Engineering Mathematics, Washington, DC, 2017.

[8] U. S. Bureau of Labor Statistics, STEM Occupations: Past, Present, and Future, Spotlight on Statistics, 2017.

[9] Hayashi. (2015). Current Status on Science and Technology in ASEAN Countries. Japan Science and Technology Agency (JST). [Online]. Available: https://www.jst.go.jp/crds/pdf/en/CRDS-FY2014-OR-02_EN.pdf

[10] T. K. Wie, "Channels of International Technology Transfer in Indonesia: A brief survey," Working Paper Series, 2001, no. 32.

[11] J. W. Forrester, Industrial Dynamic, 1st ed. Massachusetts Institute of Technology Press, 1961.

[12] J. D. Sterman, Business Dynamics, Boston, McGraw-Hill/Irwin, 2000.
[13] F. Ewout and L. J. Thomas, "Technological development and economic growth in Indonesia and Thailand since 1950," ASEAN Economic Bulletin, vol. 23, no. 3, pp. 303-324, December 2006.

[14] Manual on the Measurement of Human Resources Devoted to S\&T Canberra Manual. OECD Available:http://www.oecd-ilibrary.org/science-and-technology/meas urement-of-scientific-and-technological-activities_9789264065581-e $\mathrm{n}$

[15] A. Laudeline and S. Jerry. Human Resources in Science and Technology Measurement Issues and International Mobility, OECD: 2001.

[16] I. J. Asmara, E. Achelia, M. Akbar, R. Rahmaida, and M. Arifin, "Indonesia's national HRST scenario 2025 in research report, center of science and technology development studies," Indonesian Institute of Sciences, 2015.

[17] National Science Foundation (NSF). [Online]. Available: http://www.nsf.gov/

[18] R. J. Carlos, N. Chávez, and L. César, "A system dynamics model of science, technology and innovation policy to sustain regional innovation systems in emerging economies," Int. J. Innovation and Regional Development, vol. 6, no. 1, 2015.

[19] U. Mauricio, P. Ricardo, V. Gregorio, and C. Elias, A Preliminary Model of Innovation Systems, 2012.

[20] P. H. Joon, O. S. Hong, and K. S. Joon, "Leverage strategy to national R\&D investment in Korea: A system dynamics approach,” 2004.

[21] T. Muhammad, "The role of technology in Indonesian economy: A system-dynamics model," Journal of $S \& T$ Policy and $R \& D$ Management, vol. 12, no. 2, pp. 99-114, 2014.

[22] K. Andjelka and A. Zagonel, "Science, technology, engineering, and mathematics (STEM) Career Attractiveness," in Proc. the 27th International Conference of the System Dynamics Society, 2013.

[23] Systemdynamics. [Online]. Available: http://www.systemdynamics.org/conferences/2009/proceed/index.htm 1

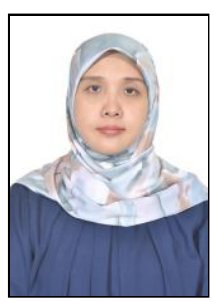

Elmi Achelia was born in Jakarta on 1984.She received her bachelor in computer science from IPB in 2005 and master degree in information technology from University of Indonesia in 2012

Elmi is a researcher in Center of Science and Technology Development Studies, Indonesia Institute of Science (LIPI). Joined with LIPI since 2006. Currently focus in science and technology policy research, specifically in forecasting science and technology resources using System Dynamics method. Also interested in research at field of computer science and information technology, as well as previous research field in data mining and big data visualization.

Her latest article in International Journal of Social Science and Humanity vol. 7, no. 6, pp. 494-500 titled "The Impact of Education on National HRST Performance" published in 2017.

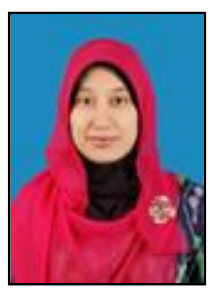

Indri J. Asmara was born in Medan Indonesia, January 4th 1981. She received her bachelor degree in computer science in 2002 and master degree in information technology in 2012 at University of Indonesia, Jakarta, Indonesia.

She is a researcher in center for S\&T Development Studies at Indonesian Institute of Sciences in Jakarta, Indonesia. The field of study is S\&T management and S\&T Policy.

She has several publication such as (1) Technological Capability Upgrading and Entrepreneurship: Case Study of Selected Indonesian Fish Processing Companies published on STIPM Vol.1 No.1/July/2016. ISSN: 2540-9786, (2) Technological Convergence in Indonesian Firms: Cases of Biobased Chemical Product Innovation published on ASIAN Journal of Technology Innovation, and published online on June $25^{\text {th }} 2015$, DOI: 10.1080/19761597.2015.1011259, (3) Linking the Supply on Demand of Indonesia Human Resource in Science and Technology on the Black Swan Phenomenon Perspective published on ACEID2017 proceeding. The past two years she has been done research about Human Resource that devoted on $\mathrm{S} \& \mathrm{~T}$ in Indonesia. 


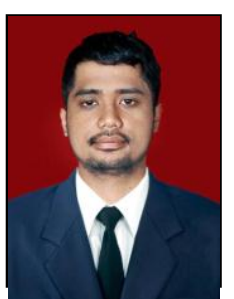

Maulana Akbar was born in Bandung, March 17th, 1989. He graduated from Undergraduate Program in Statistics, Padjadjaran University, Indonesia in 2013.

$\mathrm{He}$ is a junior researcher in Research Center of Science and Technology Development (Pappiptek-LIPI) since 2015. His specialization is on Science and Technology Policy, so be has been focusing on Human Research in Science and Technology research project for the las three years. His publications are Standardization, Innovation, and Competitiveness In Indonesia: Review of Act Number 20 Year 2014 About Standardization and Compatibility Appraisal (Amteq, 2015), Production and Consumption of New and Renewable Energy Projection comparability of Indonesia and countries in the world (Forum Iptekin - 2016).

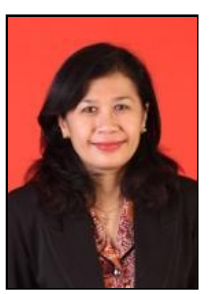

Nani Grace Berliana was born in Jakarta on October 24, 1966. First earned a bachelor's degree, majoring in Mathematics at University of Indonesia - Indonesia, in 1985. Second, Master degree on Women Studies at University of Indonesia in 1998.

She has worked for more than 20 years at Research Center for Development of Science and Technology Indonesian Institute of Sciences.

She was a Head of Sub Division of Research Cooperation on 2000 until 2002; head of sub-field of Measurement and Science and Technology Parameters on 2002 until 2010; Head of Information Systems and Management of Science and Technology on 2011 until 2014 and Head of Research and Dissemination Research Division on 2014 until 2017. Since 2002 to date, she is a researcher in business R \& D and innovation, conducting measurement or R \& D and innovation. During the last four years doing research on the modeling of Science and Technology Human Resource.

Dra. Nani Grace Simamora, M. Hum has some scientific publications include Indonesian S\&T Indicators, Jakarta, LIPI Press, 2015; The Atlas of Islamic World Science and Innovation country Case Study Indonesia, Turki, OIC, 2014. Science and Technology in Indonesia-in Brief, Jakarta, Pappiptek, 2014. Study on the Status Science \& Technology Development in Indonesia, 2012. PAPPIPTEK-LIPI; Study on Implementation and Utilization of Mini / Micro Hydro Power Plants (PLTMH) for Increasing Productive Enterprises of Rural Communities, LIPI Press, 2010.

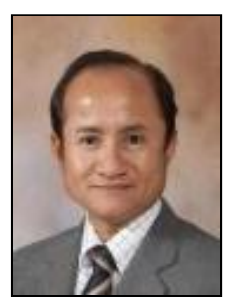

Muhammad Tasrif graduate from Electrical Engineering at ITB and Master of Engineering in Industrial Engineering and Management at Asian Institute of Technology. Doctoral degree completed at ITB in Engineering Science with a dissertation on system dynamics modeling.

He has written academic articles in several national and international journals such as Journal of Energy Policy and Journal of Development Studies. He has also given presentations at international conferences on energy policy, system dynamics, and simulation and modeling. Research interests include energy policy, modeling and simulation, and renewable energy.

Active in national committees include National Implementing Committee for Promotion of Renewable Energy, Energy Efficiency, and Greenhouse Gas Abatement and Independent Supervisors of Basic Electricity Tariff Implementation. 